\title{
Sustainable Strategy for Piracy Management in Nigeria
}

\author{
Lawal B. Dogarawa ${ }^{1}$ \\ ${ }^{1}$ Department of Planning, Research and Data Management Services, Nigerian Maritime Administration and \\ Safety Agency (NIMASA), Lagos, Nigeria \\ Correspondence: Lawal B. Dogarawa, Department of Planning, Research and Data Management Services, \\ Nigerian Maritime Administration and Safety Agency (NIMASA), No. 4 Burma Road, Lagos, Nigeria. E-mail: \\ lbdogarawa@yahoo.com
}

\author{
Received: January 19, 2012 Accepted: August 8, 2012 Online Published: October 9, 2012 \\ doi:10.5539/jms.v3n1p119 URL: http://dx.doi.org/10.5539/jms.v3n1p119
}

\begin{abstract}
Piracy is a universal hostility that leads to loss of valuables including the lives of crew members, ships, monies, supplies and cargoes. Piracy is an international crime without universally acceptable ways to control it. Piracy and armed robbery at sea increase and decrease in opposite directions when there is more or less government control measures respectively. It is believed that attacks are being under-reported because successful attacks tend to reflect negatively on the master's competence; it embarrasses the coastal State where the act occurs and also increases insurance cost and at the same time disrupts the vessel's schedule that is caused by marine board investigation. Pirates employ ambush tactics, send distress signals to unsuspecting ships, falsify documents, impersonate as security officials, attacks big ships, monitor ship-to-shore communications and operate swiftly and change location. The challenge of piracy in Nigeria includes ensuring that all ships within the country's territorial waters are duly registered and the rehabilitation of youths that were abandoned political touts who turned into piracy as a means of livelihood and the provision of adequate resources for constant sea patrol. Sustainable administration of piracy in Nigeria can be archived through moral suasion, encouragement of piracy control volunteers, continuous safety and security training for crew and port officials as well as the introduction of check-points for all ships within the nation territorial waters.
\end{abstract}

Keywords: piracy, sea, ships, international crime, Nigeria, marine board, sustainable administration

\section{Introduction}

Over several centuries, the global concern by governments and businesses regarding shipping was technological improvement that will enable ships to carry larger quantity of cargo and to eliminate pollution from ships. More than two decades ago however, increase in the menace of piracy and armed robbery at sea also began to attract serious attention which eventually led to the establishment of the International Maritime Bureau (IMB). The IMB is the centre where incidents of sea piracy and armed robbery attacks are globally being reported to.

Kerchove (1961) defines piracy as robbery, murder, or forcible depredation on the high sea, without lawful authority, in the spirit and intention of universal hostility. He adds that piracy are done without authority from any sovereign state and under condition which make it unfair to hold any state responsible for their commission.

It follows therefore that piracy involves attacks leading to loss of valuables, killing, injury and disappearance of the ship and/or crew. It is a universal hostility because the act generally affects ships of nations other than where the attacks take place. It is also a universal hostility because the cargoes involved usually belongs to different nations or businesses of different countries and crews of different nationalities. However, cases of piracy a more prevalent in certain places of the world and in recent times, Nigeria has assumed a status of one of the dangerous areas in the world for piracy attacks.

Consequently, answers need to be found for certain pertinent questions including: What are the remote and immediate causes of piracy and armed robbery in Nigeria? Who are involved in piracy attacks and how do they operate? How does the Nigerian piracy cases compare with the prevalence in Africa and the world? What are the challenges of piracy to government and businesses? What measures can be taken to have sustainable control of piracy and armed robbery in Nigeria?

This article attempts to answer these questions. It relied heavily on data sourced from various Internet websites where information of both general and specific nature regarding piracy and armed robbery at sea was offloaded. 
Statistical information obtained from the IMB was used to compare the Nigerian situation with that of the African region and the world. Various challenges were identified and strategies were recommended to tackle them.

\section{Overview of Piracy and Armed Robbery at Sea}

Piracy and armed robbery at sea increase and decrease in opposite directions when there is more or less government control measures respectively. The prevalence figures for any country or region and invariably the world at large also depends on the extent to which ships attacks were reported to the IMB; the world body that collates piracy incidences. Following the International Maritime Organisation's (IMO) resolution A683 (17) of 1991 that requires Member governments to report all cases of sea piracy attacks, a total of 1,587 incidents were reported to the organisation in nine years from 1991 to 1999. However, despite this large number of the reported cases, estimates by the IMO suggest that incidents of piracy and armed robbery against ships were being under-reported. Attacks were under-reported principally because, successful attacks tend to reflect negatively on the master's competence, embarrasses the coastal State where the act occurs and also increase insurance cost and disrupt the vessel's schedule that would be caused by marine board investigation.

Table 1 below shows six year global piracy prevalence, those that occurred within Africa and the number of cases in Nigeria between 2003 and 2007.

Table 1. Comparative sea piracy cases in the world, Africa and Nigeria (2003 - 2007)

\begin{tabular}{llllllll}
\hline & 2003 & 2004 & 2005 & 2006 & 2007 & \multicolumn{2}{l}{$2003-2007$} \\
\hline World & 445 & 329 & 276 & 239 & 263 & 1552 & $100 \%$ \\
Africa & 93 & 73 & 80 & 61 & 120 & 427 & $27.5 \%$ \\
Nigeria & 28 & 28 & 16 & 12 & 42 & 137 & $8.8 \%$ \\
\hline
\end{tabular}

Source: Annual Report for 2007 by the International Maritime Bureau

It would be observed that out of a total of 1,552 piracy cases in the six year period in the world, 427 or 27.5 percent and 137 or 8.8 percent took place within Africa and Nigeria respectively. The number of attacks in Nigeria also represents 32 percent of the total cases recorded in Africa during the period. This high degree of piracy cases indicates either lack of strong control measures by authorities in Nigeria or the increasing rate of sophistication by pirates in their operations.

\section{Causes of Piracy and Factors Responsible for Its Increase}

Piracy and armed robbery against vessels continue to challenge maritime security strategies in the world predominantly in places of heavy commercial maritime activity that have significant political and economic instability or in areas with inadequate maritime law enforcement capacity. Today's pirates and criminals have the audacity to redirect large ships because of the sophisticated level of their operations and the communication equipment they carry. The following have been identified as some of the specific factors that cause and/or facilitate piracy and armed robber at sea:

1). Presence of several islands especially where such islands are mostly uninhabited which enable the pirates to easily retreat.

2). The massive size and slow speed of deep sea vessels makes them vulnerable to attacks by pirates especially when they are in narrow or restricted channels, operating at night, during time of poor visibility or while approaching port.

3). Increase in the number of crew with fake certificates on board flag of convenience ships who may be connected to pirates and may provide cargo and rout details to them.

4). There is also collusion between crew and pirate groups. Sometime the crew are motivated by poor maintenance from shipowners including delay in payment of wages and salaries.

5). Inadequate information exchange between law enforcement agencies and disputes between neighbouring countries over territorial limits as in the case of Bakassi between Nigeria and Cameroun.

6). The hard economic situation prevailing in the prevalent regions concerned. 
7). Lack of continuous training for anti-piracy squad and public enlightment campaigns to create awareness on the implications of buying piracy spoils.

8). Lack of training and retraining of crew on how to deal with piracy attack because of relaxed government regulations on safety training for seafarers.

9). Coastal length and claims of territorial waters by countries which extends up to 200 nautical miles. The long coastline and wide territorial waters jurisdictions require huge amount of both human and material resources to maintain $24 / 7$ surveillance in all the areas.

10). Inadequate resources including funding for purchase of modern communication equipment, patrol boats and helicopters that are to be made available to the law enforcement agencies.

11). The time lag between response and the hour the incident was reported,

\section{Pirates Method of Operations}

Laurie Thomas (2005) notes that when you say the word "pirates" many adjectives come readily to mind. He argues that in today's world, the correct adjectives to describe them are dangerous, pitiless, well organised and ever increasing. He states that pirates have been mentioned by Hemer in The Odyssey; and, Julius Caesar himself was captured by pirates and was not released until after payment of enormous ransom.

In the Malacca Strait which is plied by about 200 to 600 ships daily, pirates board steaming ships at night undetected making their way to the ship's bridge and overpower the watch-keeper then get to the master and crew for money and other valuables.

Generally speaking, pirates employ ambush tactics by stalking, siting, stopping, shocking, smothering, securing, searching, snatching and scramming in order to launch a successful attack on a ship. Thus, the prospective target ship is selected, method of attack decided then halts the vessel sometimes through misleading distress signal while the attacker rush to execute their motive by seizing the ship, cargoes or other valuables after over-powering the crew without leaving any trace (Mitchell, 2004).

Over the years, pirates have become more violent in their attacks with 23 crew on board MV Cheung shot dead and their bodies thrown into South China Sea in 1998 with only six recovered while in 1999, Alondra Rainbow on voyage from Kuala Tanjung in Indonesia to port of Mike in Japan had its 17 crew members put in an inflatable liferaft and set adrift for 11 days before they were rescued by fishermen.

The IMB categorised the type of violence by pirates into six which are shown in the first column of Table 2 . Whereas a total of 433 violent cases were recorded in the world, hostage taking accounted for 292 in the world. Hostage taking also occurred 243 out of a total of 338 cases in Africa and 36 out of a total of 97 attacks in Nigeria in 2007 alone.

Five crews lost their lives during the year; out of which, four occurred in Africa and two were in Nigeria. Violent cases leading to killings of crew in Nigeria represents 40 percent and 50 percent of the world and Africa cases respectively. Piracy attacks in Nigeria were indeed very violent. In addition to the killings, 15 crews were injured in Nigeria in 2007 out of 35 global cases and 26 in Africa.

Apparently, pirates operate in various forms and at different water locations. In specific terms, their modus operandi includes the following:

1). Pirates attack big ships with smaller number of crew who invariably cannot provide adequate protection for the vessel. Encounter with pirates in high seas is often very dangerous with crew losing their lives and their bodies jettison overboard so that there can be no witnesses to the act.

2). Pirates also guise as officials and attempt to stop and board ships by wearing uniforms usually armed with low velocity weapons such as pistols and in a number of cases with assault rifles. However, there were also cases where Coast Guard operatives, corrupt drug agents and law enforcement officials are involved in piracy in East Asia, Latin America and African countries.

3). Pirates may waylay ships (mostly fishing trawlers) with faster boats, synchronise their speed with that of the target, attack swiftly and take away the fish catch, petroleum products and sometimes boat, the trawler itself or engine. 
Table 2. Types of violence used by sea pirates in 2007

\begin{tabular}{llll}
\hline & World & Africa & Nigeria \\
\hline Hostage Taking & 292 & 243 & 36 \\
Kidnapping/Ransom & 63 & 60 & 40 \\
Threat to Crew & 6 & 3 & 2 \\
Assault to Crew & 29 & 2 & 2 \\
Injury to Crew & 35 & 26 & 15 \\
Killing & 5 & 4 & 2 \\
Crew Missing & 3 & Nil & Nil \\
Total Cases & 433 & 338 & 97 \\
\hline
\end{tabular}

Source: Annual Report for 2007 by the International Maritime Bureau

4). Pirates equally attack ships in order to steal cash from the master's safe meant to settle operational expenses.

Table 3. Types of arms used by sea pirates to attack in 2007

\begin{tabular}{llll}
\hline & World & Africa & Nigeria \\
\hline Guns & 72 & 44 & 19 \\
Knives & 67 & 28 & 14 \\
Other Weapons & 14 & 4 & 2 \\
Not Stated & 110 & 44 & 7 \\
Total & 263 & 120 & 42 \\
\hline
\end{tabular}

Source: Annual Report for 2007 by the International Maritime Bureau

5). Pirates similarly mount surveillance on crew and trail those who go to town from ports, listen to their discussion about the vessel route and type of cargo on board as well as intercept ship-to-shore communications in order to determine which ship to attack.

6). Pirates endanger their own lives and the lives of the crew by damaging navigational aids, dumping dangerous cargoes into the sea and jettisoning crew overboard without adequate food and water.

7). Pirates may conspire with crew members or stowaways, use fake cargo and personal documents, jumps into waters to evade capture or use their connections in judiciary and public offices to avoid detention when arrested. They are also treated like kings by their communities when they returned home after disposing the cargo or re-registering the ship which may be discovered in the long-run.

\section{Financial Implications of Piracy}

Sea pirates are criminals who attack all types of water crafts on the high-sea, along the coasts and possibly inland waterways in order to steal valuables including tanker vessels. Although it is said to be grossly underestimated, the global losses from piracy attacks have been put at approximately $\$ 16$ billion annually (Mitchell, 2004). In 2001, the UK department for international development estimates that guinea is losing \$100 million every year in stolen fish as a result of piracy activities (Greenpeace, 2001).

The success and methods of pirates in one region influences other criminal minded people in another region to start piracy attacks. The Movement for the Emancipation of Niger Delta (MEND) started after they discovered that pirates in the Malacca Straits receive average of US\$100,000 in ransom per ship with which they fund their operations (Mitchell, 2004). The MEND attack ships and kidnap prominent people for ransom to purchase high-speed boats and guns to get to the Atlantic Ocean to attack tankers. They also steal about 100,000 barrels of crude oil per day in order to sustain what it calls "struggle for greater autonomy" (IRINNews, 2004).

\section{Global Piracy Control Measures}

The sophistication of modern pirates makes it difficult for one country to control. They carry heavy weapons, operate on high sea or move between the territorial waters of different countries. This was why in 1991, International Maritime Organisation (IMO) Assembly adopted resolution A683 (17) which was tagged Prevention and Suppression of Acts of Piracy and Armed Robbery Against Ships so that Member Governments will report all incidents of piracy and armed robbery against ships under their flags to the organisation. 
Also, in 1992, the Secretary-General of IMO having been so concerned with the piracy prevalence especially in the Malacca Strait initiated a Working Group composed of experts from ten IMO Member countries, including experts from Indonesia, Malaysia and Singapore the three littoral States of the Malacca Strait, to prepare a report outlining the problem in the Strait of Malacca. The report was then considered by the Maritime Safety Committee (MSC) at its sixty-second session in May 1993 resulting in the issuance of MSC Circular Nos. 622 and 623 on Recommendations to Governments for preventing and suppressing piracy and armed robbery against ships and Guidance to shipowners and ship operators, shipmasters and crews on preventing and suppressing acts of piracy and armed robbery against ships respectively.

Prior to the MSC Circulars however, the three littoral States had already established Working Group in the region in response to their concerns over the situation in the Malacca Strait. Their Working Group implemented a co-ordinated patrol and other counter-measures in the region starting from 1992 which eventually tremendously reduced the number of attacks in the region such that in 1998, only six piracy and armed robbery incidents were reported in the Malacca Strait.

In January 2000, Chinese courts sentenced 13 pirates to death and 14 others in August to various jail terms with death sentence for one of them for killing 23 crew members of Cheung Son in 1998 and 21 hijacked seamen on Panama-registered vessel in 1999 that were rescued respectively.

\section{Maritime Piracy in Nigeria}

Wikilpedia (2007) notes that piracy in Nigeria is common in the Niger Delta areas where law enforcement is scarce and waterways are numerous especially in the Bonny Island. Lagos is also another area that is infested with pirates' attack. Aderibigbe (2008) on the other hand reports that over 40 cases of violent armed robbery were recorded on Nigerian waters in less than six months without any arrest and there was no hope that arrest could be made on future cases because piracy attack, in most cases, takes place within a spate of 30 minutes to one hour, but the nearest external assistance if any may not arrive earlier than some eight hours after a distress signal has been sent out. Sometimes, the pirates stay as much as 48 hours on board the vessels.

Table 4. Nigeria's percentage of arms used in sea piracy attack in 2007

\begin{tabular}{lll}
\hline & $\begin{array}{l}\text { World } \\
(\%)\end{array}$ & $\begin{array}{l}\text { Africa } \\
(\%)\end{array}$ \\
\cline { 2 - 4 } Guns & 26.4 & 43.2 \\
Knives & 21.0 & 50.0 \\
Other Weapons & 14.3 & 50.0 \\
Not Stated & 6.4 & 16.0 \\
Average & 20.0 & 35.0 \\
\hline
\end{tabular}

Source: Computed from Table 3

There were also cases of threats to blow up the crew and the vessels if ransom was not paid. Earlier in January 2008 alone, over 30 attacks on fishing trawlers were recorded by the Fishing Trawlers Association (FTA) with five people killed in two days. Half of the 30 deaths recorded from pirates attack around the world in 2004 between January and June occurred in Nigerian territorial waters.

Nigeria represents an overall average of 20 percent and 35 percent of the various arms used in sea piracy attacks in the world and in Africa respectively in 2007. Specifically, 26.4 percent of use of guns in the world and 43.2 percent in Africa were in Nigeria. On the other hand, 50 percent of use of knives and other weapons in the African region took place in Nigeria with 16 percent additional case of the use of unspecified types of weapons.

\section{Causes of Maritime Piracy in Nigeria}

We have already seen 13 factors that are globally attributed to the cause of piracy and armed robbery at sea. In this Section, we shall discuss the remote and immediate causes of the criminal act in Nigeria. It would be observed that while some of the universal factors are present in Nigeria too, there are certain unique incidents that put piracy cases in the country under a different category. Some of the causes of piracy and armed robbery attacks in Nigeria include:

First, there is lack of comprehensive records of ships operating on the Nigerian waters which would have provided easy identification and assistance in case of piracy attack. Activities of fishing trawlers are areas that need to be streamlined. Fishing trawlers operators are regulated by the federal ministry of agriculture based on 
their fishing activities but the trawlers they used to fish are part of the transport hardwares that should be regulated by federal ministry of transportation through its safety administration agency. There is statutory charge especially under the Cabotage regime of the country which the fishing trawlers do not want to pay but at the same time, trawler operators like to benefit from search and rescue as well as other safety operations being provided by the safety administration agency. There is no link so far between the records of the ministry of transportation and that of agriculture in this regard.

Second, there is inadequate number of functional ships, albeit in a vast coastline and territorial waters that is put at 420 nautical square miles, to perform the task of monitoring or surveillance. Related to this is the inability of the Nigerian authorities to monitor ships directly through satellite without using third party nations. Incidentally, most of the ships littering in the Nigerian waters which are involved in oil theft belong to some of the big nations Nigeria approaches for satellite services to monitor and capture. This makes the whole exercise more difficult because of the economic interests.

Third, there is also the seeming neglect of the marine police, who incidentally are more civil than the navy, in the task of fighting piracy in the country. The Nigerian police force were not invited to participate in the last piracy conference held at Abuja despite their rich network of police posts even within the piracy infested areas.

Fourth, piracy increases in Nigeria because of the proliferation of weapons in the oil-rich Niger Delta region where armed gangs trade stolen crude.

Fifth, there is the problem of massive unemployment among youths (many of them may be cadets trained at the maritime academy, Oron and the institute of oceanography and marine technology, Lagos who do not have the opportunity to gain sea experience onboard merchant ships) as well as armed militias who are recruited into crime cartels (IRINNews, 2004).

Sixth, there is increased security problems on land which competes for the security fund that would have adequately cater for the security problem at sea. Nwaneni (2007) estimates that more than 10 patrol boats (instead of the present four) are required to effectively monitor the country's territorial waters and each patrol boat costs about $\$ 15$ million.

Seventh, pirates also attack for political reasons although they still attached financial request. Pirates are hired to attack political opponents which they carry out by kidnapping close family members. It is alleged that the increase in piracy and armed robbery at sea in the Niger Delta region came about as a result of recruitment of political touts who were used to rig 2003 and 2007 elections in the area and later abandoned after being armed and trained on the use of weapons.

\section{Pirates' Methods of Operation in Nigeria}

Pirates in Nigeria operate in manners similar to those in other parts of the world. Between 1982 and 1986, Nigeria had the highest reported number of cases of piracy and armed robbery in West Africa. About 25 cases were reported annually, mainly against ships at anchor awaiting berth.

Table 5. Status of ships during actual and attempted attacks in Nigeria

\begin{tabular}{lllll}
\hline & 2007 & & 2008 & \\
& Actual & Attempted & Actual & Attempted \\
\hline Berthed & 5 & Nil & 5 & Nil \\
Anchored & 19 & 5 & 6 & 2 \\
Steaming & 9 & 1 & 3 & 2 \\
Not Stated & 3 & Nil & Nil & Nil \\
Total & 36 & 6 & 14 & 4 \\
\hline
\end{tabular}

Source: IMB Annual Report for 2007 and Half Year Report for 2008

Typically, a gang of about 10 people would board the ship at night, threaten the crew with knives, overpower them and then go on to break into cargo containers and steal their contents.

In recent time, pirate rather took oil workers into hostage and demand for ransom before releasing their victims after payments. They attacked and kidnapped oil workers in broad-day light inside Port Harcourt city apart from attacking oil service ships to get their captives. The most recent method is that, gangs numbering over 2,000 armed with automatic rifles and increasingly with rocket propelled grenades cruise along speedboats and barges 
attack and find cover in the maze of creeks and rivers intertwined with mangrove swamps that make up the Niger Delta where the River Niger empties into the Atlantic Ocean (IRINNews, 2004). In the Lagos area however, pirates still attack at anchorage, or when the ships are berthed, or steaming.

From Table 3, we noted that in 2007, a total of 263 attacks occurred in the world out of which 42 took place in Nigeria. Table 5 above however shows that out of the 42 incidences in Nigeria, 19 occurred when the ships were anchored, nine and five took place when the ships were steaming and at berth. Within the half year of 2008 however, out of a total of 18 cases, 14 actually occurred from which five and six were at berth and anchored respectively.

Out of the total number of ships attacked in each of the years in 2003 through 2007, only two, five and two were Nigerian flag ships which were attacked in 2003, 2004 and 2007 respectively. In terms of violence within the first half of 2008, Nigeria recorded

\section{Piracy Control in Nigeria}

Following the annual average of 25 piracy cases in the 1980s, Nigerian government stepped up security in the country which resulted in reports of occasional isolated incidents from Lagos and Bonny ports that were actually the hot spots for such attacks by the end of 1986 .

The sharp increase in reported cases within the last five years has also led to the establishment of a Joint Task Force (JTF) to monitor and control sea piracy and armed robbery in the country. There have been several encounters between the JTF and the pirates which resulted in arrests and killing of some pirates especially in Port Harcourt area of the Niger Delta region.

\section{Challenges of Piracy in Nigeria}

Mitchell (2004) opines that piracy worldwide is declining, but it is not likely to be totally eradicated. Conversely, piracy in Nigeria is on the increase partly because the matter has been politicised through the support of some international communities that benefits from the crime. This has made the challenges of piracy in Nigeria to require both short and long term measures to address them. Some of the challenges are as follows:

1). Losses due to piracy are very difficult to assess in monetary terms; some of the losses, such as the death of an experienced master mariner as a result of successful piracy attack, can only be replaced after a very long time.

2). Difficulties in distinguishing fishermen who carry out genuine trade on the high seas and criminals who stay afloat to monitor ships' movements in order to gauge best time to attack.

3). How to reduce the losses by shipowners as a result of piracy attacks especially when it involves cargo theft in the face of globalisation by which the business of government is supposedly limited to facilitate shipping activities through regulatory framework and not to distort market forces through the provision subsidy.

4). There is the task of rehabilitating youths who have been recruited into criminal cartels and have been exposed to getting their income through violent means. Most of the youths were drop-out from schools whose parents may be poor and had grown up in society without moral parental background. Pirates readily accepted outcasts from traditional societies, perhaps easily recognizing kindred spirits, and they were known to welcome them into the pirate fold. Such practices within a pirate crew were tenuous, however, and did little to mitigate the brutality of the pirate's way of life.

5). There is again the problem of correcting perceived neglect of the Niger Delta region by the federal government. People in the area hardly asked their leaders questions on what they do with the money they received through monthly federal allocation. The federal government alleges that Niger Delta leaders divert monies meant for development purpose and then set the people against it. Indeed, people in the region believed that other Nigerians are mere parasites who reap where they did not saw; referring to the oil income that goes into the federation account that is shared between the three tiers of governments in the country.

6). Another challenge is how to stop illegal oil bunkering in the Niger delta area. Activities of the pirates have already drawn illegal oil buyers and armed traders to the Gulf of Guinea coast off Nigeria which avails crude from pipelines of multinationals.

7). Although riverine communities are generally into fishing, boat construction and boat operation businesses, some of the people are also into crop and other forms of farming. However, farming is increasing becoming difficult because of oil pollution in the area which even makes potable water for drinking and domestic use scarcer. 


\section{Recommendations}

Piracy and armed robbery at sea is becoming more sophisticated and complex by the day. Piracy control measures employed on the other hand are becoming ineffective because of the illusive ways the attacks are being carried out. The effectiveness of any piracy control measure therefore depends on the modus operandi of the pirates, the region they operate and the resources being committed by government and the maritime business community. On a general note, piracy can be put to check by constant patrol. In the case of Nigerian situation however, the following measures are equally recommended:

1). There should be continuous training for both crew and law enforcement agents as well as the introduction of reasonable hazard allowance for the maritime security forces and seafarers.

2). There should also be less dependence on paper piracy control measures by all maritime organisations including the IMO through demonstration of resource mobilisation and deployment to achieve practical results.

3). Government should ensure timely investigation of attempted and actual piracy attacks. Government should also set up Maritime Crime Courts (MCC) where pirates will be court-marshalled including the possibility of passing death sentences against maritime crime perpetrators. The starting point to archive this however is to domesticate the United Nations Convention on Law of the Sea (UNCLOS) in order to get full international supports for the measures.

4). Use of moral suasion to encourage local communities in the coastal areas to monitor the activities of pirates and report their places of hiding as well as to assist in apprehending them.

5). Strengthening the Joint Task Force (JTF) by providing them with at least 50 speedboats, 5 helicopters and adequate number of modern communication equipment. In addition, radar system that enables the Regional Maritime Coordination Centre (RMCC) to monitor and track all classes and size of vessels that traverse Nigeria's territorial waters on a twenty-four-hour basis should be installed. The radar provides the course, speed, and position of any vessels operating within its operational range. This is a key weapon for the country in combating illegal sea activities. However, since ships involved in crime turn off their communication equipment in order to avoid detection, maritime authorities must persuade government to launch another satellite for the country that will orbit around Nigeria more frequently in order to improve ships monitoring.

6). Recruitment of Piracy Control Volunteers (PCV) who will be properly trained on safety and tactical ways to overpower pirates with minimal risks. The PCV should be drawn from staff of government maritime agencies and oil firms. This will provide opportunity for proper identification, monitoring and control of the PCVs.

7). There should be concerted efforts to identify all vessels operating on the Nigerian waters through registration and on-line verification of registration status by the JTF in their various locations. Care must be taken to secure the vessels database against illegal access and possible alteration of the records by pirates and their conspirators.

8). Ship crews should be more vigilant especially when sailing in known danger areas of the Niger Delta and Lagos ports. The RMCC should broadcast repeated alerts to ships in the Nigerian waters and port approaches in order to keep them on guard over likely pirates attack.

9). Sea checkpoints should be introduced within Nigeria's territorial waters especially around entry areas to all the ports which should also be complemented by constant patrol in order to provide added protection to the ships as well as to security forces at the checkpoints. Ship captains should be required to provide their crew lists at the checkpoints and must be physically identified before the ship is allowed to proceed to port as well as before they can have access to their vessels at the port if they go ashore.

10). Government should encourage ex-servicemen especially naval officers to set up companies to provide maritime security services. Ex-servicemen may be recruited through the Nigerian Legion. Maritime operators can engage the services of such security companies to provide armed escorts to their ships and guard oil and gas floating assets and their convoys. The ex-servicemen are men of discipline with rudimentary training and experience in crime fighting and therefore reliable. Ex-military and police intelligence officers can also be encouraged to go into joint venture with private security companies in order to have a one-stop brigade for combating piracy and armed robbery at sea. This idea has already been tested by road transport operators who requested for armed police attachment to their luxurious buses as escorts. In a country without proper retirement plans for our ex-service personnel, maritime security services can provide opportunity for useful retirement life rather than drafting serving security personnel away from their primary duties. 


\section{References}

Adelanwa Bamgboye. (2008). West Africa: Piracy - FG to protect 60 Percent of Ecowas Seaborne Trade in Daily Trust. Retrieved from http://www.allafrica.com/stories/200805010204.html

Afrol News. (2008). Kenya to fight piracy off Somali's coast. Retrieved from http://www.afrol.com/articles/1915,

BARS. (2008). Maritime piracy Suppression. Retrieved from http://www.piracysuppression.com/

Colin, L. Mitchell. (2007). Countering Maritime Terrorism in the Caribbean Sea and the Atlantic Ocean: Implications of possible Maritime Terrorism in the Caribbean; A Thesis Presented to the Faculty of the U.S. Army Command and General Staff College in Partial Fulfilment of the Requirements for the Degree of MASTER OF MILITARY ART AND SCIENCE General Studies, University of the West Indies, St. Augustine, $2004 \quad$ Fort Leavenworth, Kansas. Retrieved from http://www.maritimeterrorism.com/wp-content/uploads/2008/04/countering-maritime-terrorism-in-the-carib bean-sea.pdf

Dana Robert Dillon. (2000). Piracy in Asia: A Growing Barrier to Maritime Trade. Retrieved from http://www.heritage.org/research/reports/2000/06/piracy-in-asia-a-growing-barrier-to-maritime-trade

Dele Aderibigbe. (2008). Piracy may continue on Nigerian waters. Retrieved from http://www.tribune.com.ng/07052008/Maritime.html

Erik Barrios. (2008). Casting a Wider Net: Addressing the Maritime Piracy Problem in Southeast Asia. Retrieved from http://www.bc.edu/dam/files/schools/law/lawreviews/journals/bciclr/28_1/03_TXT.htm

Felix Nwaneri. (2007). Nigeria: Piracy - Nimasa, Navy Set up Joint Committee in Daily Champion. Retrieved from http://allafrica.com/stories/200712210672.html

Galrahn. (2008). The Piracy Problem, Politics and Possibilities. Retrieved from http://informationdissemination.blogspot.com/2008/04/piracy-problem-politics-and.html

Global Maritime Ports Database. (2008). Piracy. Retrieved from http://www.gd-ais.com/Capabilities/offerings/sr/GGDP/GMPDDescription.html

Greenpeace. (2001). Robbing West Africa. Retrieved from http://www.greenpeace.org/international/en/

IMO. (2002). Piracy and armed robbery against ships. Retrieved from http://www.imo.org/dynamic/mainframe.asp?topic_id=362

Inmarsat, C. (2008). Weekly Piracy Report. Retrieved from http://www.icc-ccs.org/prc/piracyreport.php

IRIN. (2004). Piracy in Nigeria. Retrieved from http://www.irinnews.org/report.aspx?reportid=50843

John, M. (2001). Options to Combat Maritime Piracy in Southeast Asia. Retrieved from http://cache.search.yahoo-ht2.akadns.net/search/cache?ei=UTF-8\&p=maritime+piracy

Laurie Thomas. (2005). Piracy 2005: A New and Major Terrorism Concern. Retrieved from $\mathrm{http} / / /$ seem.findlay.edu/news/display.asp?n46vpyrvq=GE

Liberian Flag Administration. (2008). Piracy Accident Report. Retrieved from http://www.liscr.com/liscr/Maritime/MaritimeFAQ/CasualtyInvestigationLegalQuestions/tabid/126/Default. aspx

Maria Bafi. (2006). Modern Forms of Sea Piracy and Armed Robbery. Paper presented at the International Conference on Shipping in the Era of Social Responsibility, held between 14 - 16 September, 2006 at Argostoli, Caphlonia, Greece.

Mark Bruyneel. (2001). Modern Day Piracy Statistics. Retrieved from $\mathrm{http}: / /$ home.wanadoo.nl/m.bruyneel/archive/modern/figures.htm

Rem Korteweg. (2008). Turbulent Waters in a Maritime Black Hole. Retrieved from http://www.hcss.nl/en/column/672/Turbulent-Waters-in-a-Maritime-Black-Hole-.html

Rene de Kerchove. (1961). International Maritime Dictionary (2nd ed.). Van Nostrand Reinhold Company, New York.

Sam Vaknin. (2005). Treasure Island Revisited On Maritime Piracy. Retrieved from http://samvak.tripod.com/pp161.html 
Sean $\underset{\text { http://www.wtopnews.com/?nid=385\&sid=1323167 }}{\text { Yoong. (2008). }}$ Nigeria overtakes
Indonesia

The Maritime Safety Committee. (2007). Reports on Acts of Piracy and Armed Robbery against Ships. Fourth Quarterly Report. Retrieved from http://www.imo.org/includes/blastDataOnly.asp/data_id\%3D21058/114.pdf

The Port Harcourt Telegraph. (2008). Piracy: Nigeria ranks 5th in Africa. Retrieved from http://www.thephctelegraph.com/stories/January,\%202008/2801bnews_03.html

United Kingdom. (2005). The UK Government's strategy for tackling Piracy and Armed robbery at sea. Retrieved from http://www.dft.gov.uk/pgr/security/maritime/piracy/theukgovernmentsstrategyfort4906

United States Government. (2005). National Security Strategy of the United States. Retrieved from http://www.dhs.gov/xlibrary/assets/HSPD13_MaritimeSecurityStrategy.pdf

Wikipedia. (2008). Piracy in Nigeria. Retrieved from http://en.wikipedia.org/wiki/Piracy_in_Nigeria 